from Copyright Agency Limited. For information

about such licences contact Copyright Agency

Limited on (02) 93947600 (ph) or (02) 93947601

(fax)

\title{
Breadwinning: Accounts Of Work And Family Life In The 1950s
}

\author{
John Murphy
}

Abstract
The breadwinner model became pervasive in the post-war years in Australia. While
this was built upon long-standing policy ideas of the 'family wage' and cultural
ideas of gender identity, the pervasiveness of the breadwinner model also reflected
its spread within the working class as a consequence of the prosperity of Full
Employment. This article draws on in-depth narrative interviews with men and
women about their ideas of work, family and gender identity during the 1950 s. It
focuses on the ways masculinity was bound up with the norms and expectations of
being the breadwinner. The research suggests that while the experience of being a
breadwinner was not markedly different across classes, the narratives and language
through which men describe what being a breadwinner means do show class
differences. Middle-class men tended to use a language of breadwinning as taken
for granted, while working-class men were more likely to claim an ideological or
normative commitment to being the breadwinner. Similarly, there are marked
differences in the extent to which being a breadwinner also meant men were
domineering within the family, though this had little to do with class. These differences
are also less significant than the fact that the attitudes of both middle-and working.
class men were firmly within the dominant gender culture of the period.

\section{Introduction}

The post-war years have been described by one historian as the 'high water mark' of the family model of a male breadwinner, a housewife/mother and dependent children (Gilding, 1991: 121). At the core of the breadwinner model lay expectations that men should work to provide and that masculinity was substantially derived from paid work. Accordingly, understanding what being a breadwinner meant to men is important for understanding the culture of work. But the breadwinner model was also a gender relationship, for the other half of the breadwinner was a model of motherhood and family. By definition, breadwinners have dependants. The breadwinner model meant that women were largely 
reliant on private transfers of income for their sustenance, and as a result of this dependency the model came to be associated with imbalances of opportunity and power within the family.

The breadwinner model of work and the family has a long history in Australian culture and policy, being built into the evolution of the 'family wage' system and into welfare policies predicated on the breadwinner's wage (Baldock and Cass, 1988). In the post-war years it achieved a relatively new pervasiveness in the experiences and the values of ordinary Australians. More recently, we have seen a substantial erosion of the model, as indicated by changes in family patterns, changes in women's participation rates and the restructuring of welfare and arbitration systems. It may be too early to talk of the demise of the breadwinner model, but it is clearly less central to policy institutions, ordinary family experience and gender identity, even if it lingers as the presumption around which much employment is structured (Cass and Smyth, 1998; Buchanan and Thomthwaite, 2001).

In this article I describe the sentiments and narratives of older Australian men who have been interviewed about their recollections of work and family life in the mid-1950s. I also include some discussion of how women of the same age reflected on their husbands as breadwinners. Their narratives provide a detailed insight into the ways that norms and expectations about manhood as breadwinning helped constitute the meaning of work. In addition, the interviews reflect the somewhat different meanings of work and breadwinning for middle-class and working-class men. They demonstrate how much working life and gender identity were interrelated in the post-war years, and they indicate the varied shades of meaning that the breadwinner acquired at its high water mark.

\section{The Breadwinner In Australia}

During the post-war years of Full Employment, in Australia as in many Organisation for Economic Co-operation and Development (OECD) countries, the male breadwinner model was more than usually pervasive both culturally and in ordinary people's experience. It was fundamental to the ideas of domesticity and of the family that played a major part in Australian political culture (Murphy, 2000). But this was hardly new; it was an intensification of long-standing attitudes and expectations in the gender culture in Australia. From at least the beginning of the twentieth century, the idea of the male breadwinner had been built into the fabric of a strong system of wage regulation, into a segregated labour market that institutionalised unequal pay, and into the practices and entitlements of a relatively parsimonious and residual welfare state. This regime of welfare and wages had strong support from the union movement. It helped produce a distinctive model, which Castles dubbed the 'wage-earners' welfare state', built around the central figure of the male breadwinner (Castles, 1985).

Briefly summarised, Castles' argument was that - beginning with H.B. Higgins' 1907 Harvester judgement - wages were arbitrated by the state on the principle that the 'family wage' should be sufficient for a male worker to support a dependent family. As Higgins himself wrote, 'a wage that does not allow for the matrimonial condition of an adult man is 
not fair and reasonable, is not a "living wage"' (quoted in Macintyre, 1985: 57). On the assumption that women were not providing for a family, arbitrated female wages could consequently be set lower. In turn, the system of the family wage had significant consequences for social policy. As Castles and Shirley summarise the argument:

This built-in assumption of a 'fair' wage made for a social policy development quite different from that in Europe. Benefits could be residual rather than universal, because they were only required by those with no labour market connection; benefits could be flat rate rather than earnings-related, because they were only a secondary safety net below stipulated minimum wages. (Castles \& Shirley, 1996, 91)

Hence, a strong wages system built on male employment in effect crowded out policy developments that, as in other countries, could have engaged social expenditure to moderate or even de-commodify the market. Castles' argument has been influential in Australian social policy analysis, and it has been mobilised to explain the gendering of the welfare system and the place of the Australian model in general typologies of welfare regimes. It has highlighted the ways the breadwinner model has been built into the institutions of the Australian labour market and welfare state (Baldock and Cass, 1988; Bryson, 1992 and 1995; Watts, 1997; Cass and Smyth, 1998).

The male breadwinner model has been to the fore in much recent research on contemporary changes in work, gender and policy. But the breadwinner of the past has been conceptualised as a relatively stable and known starting point against which to assess contemporary change. Thus Williams places the breadwinner at the centre of her description of 'domesticity', especially as a model of 'an ideal worker with immunity from family work' (Williams, 2000: 20). Similarly, some of the cross-national comparative work, such as that of the German sociologist of work and gender, Birgit Pfau-Effinger, has concentrated on the policy structures and cultural ideas built around the breadwinner model. But the breadwinner model is not so stable a starting point. It is important to recognise that not all breadwinner models of work and the family are the same. PfauEffinger's research demonstrates marked historical differences between West Germany, the Netherlands and Finland, and she sees these as leading to different trajectories of 'modernisation' of the family (Pfau-Effinger, 1993 \& 1999). Similarly, Diane Sainsbury has argued that focusing on a male breadwinner model in the abstract can obscure crossnational differences between what she calls 'strong' and 'weak' versions of the model (Sainsbury, 1996).

When we look at research on masculinity, there are similar questions to be raised about the breadwinner. Certainly, breadwinning has been central to ideas of manhood, in Australia as in many Western countries, and it is virtually a truism in the literature that working to be a provider is the key to men's sense of identity. In 'sex role theory' and in developmental psychology, the attainment of the breadwinner 'role' is often regarded as the criterion of manhood as successful and mature 'gender performance'. To be a man is to be a provider, and to be a provider is to demonstrate adult manhood. But some of this 
literature is highly functionalist and has been critiqued by social theorists such as R.W. Connell (1995), who argues that masculinity is more fluid than simply the attainment of a given, known and homogenous role.

Others have described the ways masculinity has been shaped historically, particularly through describing how it has been materially and culturally bound up with the changing world of work. For example, American historians of the transition from pre-industrial to industrial conditions have argued that manhood changed from being a matter of household patriarchal authority to being linked with the entitlements and responsibilities of breadwinning. As Rotundo puts it, industrialism and domesticity meant 'a man's work takes on a separate meaning and provides the chief substance of his social identity' (Rotundo, 1993:167; also Pleck, 1987; Cohen, 1993). Similarly, Steven Mintz' historical survey of American ideas and practices of fatherhood argues that the identification of manhood with breadwinning accompanied the industrial revolution. In the $20^{\text {th }}$ century 'breadwinning has been a defining characteristic of men's familial roles, helping to define men's identity, providing their feelings of self-worth, and structuring the amount of time available for their family' (Mintz, 1998: 24).

Once work was separated from the household, and if one wage was adequate to support a family, men's identity became more single-mindedly bound up with work. But Mintz argues that the breadwinner model of work and family was only gradually extended from the middle class to the working class in the United States: 'it would not be until the mid-1910s that the cooperative working-class family economy began to give way to the "family wage" economy, which allowed a working-class male breadwinner to support his family on his wages alone' (Mintz, 1998: 18, 24).

The United States has had a significantly different labour market and wage regulation system throughout the 20th century, but part of the parallel story in post-war Australia was a widespread material experience of a 'family wage' economy due to the economic boom. One effect of Full Employment in the post-war period may have been the expansion of the male breadwinner model from the middle class, who had long been able to practice it, deep into the working class, who had long aspired to the prosperity it denoted. Australian working-class men had often argued for the dignity and autonomy denoted by the breadwinner model. For example, in the Depression of the 1930 s, unions had demanded work rather than demeaning assistance, objecting to the dole because 'a man loses his manliness under such a system' (quoted in Macintyre, 1985: 65). It was a comment not only on the dignity of labour, but also on the dignity of providing. It was also a reminder that for much of the 20th century the male breadwinner model has, particularly for the working class, been an aspiration difficult to attain. But it became more feasible under conditions of Full Employment, as demonstrated in Mark Peel's nuanced study of workingclass culture in Elizabeth, where "the ability to "keep" a wife and children was crucial to masculinity' (Peel, 1995: 125).

The link between breadwinning and working-class manhood was made more powerful and poignant in the memories of families in which fathers had failed to provide during the Depression. In conditions of relative prosperity, working-class men could be 'the kind of men they expected themselves to be'. 
In the workers' city, adult male identity was defined by the role of the 'breadwinner'. Manliness was measured first and foremost in a man's ability, and responsibility, to provide for his family ... by his personal ability to provide, to hold down a job (Peel, 1985, 134).

With family memories of the Depression, providing could nevertheless seem a heavy and anxious responsibility for some men. For example, a carpenter who had grown up in a family disintegrating under the pressure of the Depression recalled:

I was very conscious that we didn't have much in the early days. I was very conscious that I'd be able to keep a job especially after the war years ... I was always worried that I wouldn't be able to provide properly, but as life turned out, it tumed out well. '

A key part of life 'turning out well' was that, in the 1950s, the breadwinner model was at its peak. Full male employment and very high union coverage produced high wages and unusually secure male employment, and enabled many working-class families to live on one income, which may in turn have helped to erase generational memories of the Depression.

A key element of the breadwinner model is the reliance of wives on private income transfers within the family. Shortly after the Second World War, a combination of lower wages for women, tax incentives for single-income families and a powerful ideology of domesticity contributed to low rates of female paid employment. Married women's workforce participation was only 8.6 per cent in 1947 . However, even during this period, it is possible to detect the stirrings of the changes that were to have a significant impact after the $1960 \mathrm{~s}$. The participation rate of married women had grown to 18.7 per cent by 1961 , and Katy Richmond noted that these ABS figures underestimated part-time work, and so should be somewhat higher (Richmond, 1974). By 1964, the participation rate for married women had continued to grow to 24.5 per cent and, of these women, one-third was working part-time (Foster and Stewart, 1991: 152, 158). Within this growth, there were distinctive differences based on ethnicity. Among non-Anglo married migrant women, participation rates were much higher - at 32 per cent by 1961 - than the overall averages. Conversely, the participation rate was extremely low among Australian-born women (Richmond, 1974). When combined with an analysis of which income groups claimed the very substantial tax benefits of the dependent spouse deduction in the 1950s, it is apparent that the single income breadwinner family was most prevalent amongst the Australianborn middle class, and was least common amongst non-Anglo born migrant, workingclass families (Murphy, 1995).

This statistical pattern during the 1950 s is a reflection of who actually practised (rather than who aspired to) the breadwinner model of a sole male earner. What was the breadwinner's sense of self? What were the meanings ascribed to being the breadwinner by both men and women? How were these meanings influenced by the experience of work, and how did they vary by the experience and the culture of class? In the project that provides the material for this article, we explored these questions through qualitative semi-structured interviews with 38 men and 48 women, who were asked to reflect back to 
their time as young parents in the mid-1950s and invited to tell us the narratives of their experience. Exploring these narratives and values through interviews makes it possible to identify the meanings and experiences of breadwinning for this post-war generation.

It is worth remembering that - against the backdrop of the Depression and then the massive disruptions of World War Two - the experience of Australians in the post-war years was a relatively novel one, just as today it is an experience largely in the past. And within the relatively uniform practice of the breadwinner model in the post-war years, there were some significant variations of narrative and meaning. The most marked of these differences were associated with variations by class, in which middle-class men were more likely to speak of breadwinning as taken for granted and natural, as part of a natural 'order of things' (which I will call 'de facto breadwinning'), while working-class men more often articulated a normative commitment to the identity of the breadwinner, with a more insistent claim that they should be the family provider ('normative breadwinning'). However, both these narratives remain firmly within the dominant gender culture of the period, and the differences between them are of nuance and tone rather than the products of fundamentally different attitudes.

Of our interviews with $38 \mathrm{men}$, all were working full-time in the 1950s, and only two were not the primary breadwinner. Of these two, one was a research chemist whose wife worked as a dentist, and each described themself as having an equal relationship. ${ }^{2}$ The other man was a printer whose wife worked as a Communist Party official. Without children, and with their eyes on other prizes, narratives of breadwinning made little sense to him. ${ }^{3}$ Of the remaining 36 men, some 22 (61 per cent) can be characterised as 'de facto breadwinners', whose stories suggest they took their position for granted as what was expected of them, while the other 14 ( 39 per cent) had narratives more ideologically and normatively committed to the idea that they ought to be the breadwinner, and that often they expected familial authority to flow from this position. Class would seem to be the main, though still only partial factor in determining this difference. The group of 'de facto breadwinners' consisted of 16 middle-class men and 6 working-class men, while the latter group of 'normative breadwinners' were made up of 10 working-class men and 4 ' middleclass men.

\section{De Facto And Normative Breadwinners}

Being a provider was clearly essential to masculine identity, regardless of class. Similarly, many women in the post-war years identified with the corresponding role of being a mother and homemaker. The following vignette illustrates these connections between work and gender identities in the lives of one working-class couple. The man concerned was one of those who took his breadwinning position for granted as part of the natural order of things.

Len was a process worker in Melbourne's western suburbs. ${ }^{4}$ He grew up in country Victoria, where his father was a salesman, and his mother was not in paid work. He left school early with little idea of the sort of work he would do and was too young for the war. 
After periods as a farm worker and builder's labourer he found work in 1946, at the age of 18 , as a process worker boiling down animal fats for glues and oils for export. Eight years later, he was made foreman, supervising a small team of workers, most of who were recently arrived migrants. He stayed in the same job for 34 years, until the factory closed. With this security of work, in 1958 he and his wife began buying the pre-fabricated concrete Housing Commission house, in which they still live. He had little interest in religion, sport, politics or drinking with friends in the pubs. Life was quiet, contained, even insular; he described his community as 'my wife and children'.

Len explicitly regarded himself as the breadwinner and the head of the household. He saw his position as 'providing money and generally helping with educating the children to the best one could, just making sure they got the best that we could give them'. Breadwinning came naturally:

... that's the only way to go. I didn't think nothing bad about having to go to work and bring money home to feed the family. I never gave it a thought really ... it was just one of those things which were taken for granted. As I said, when people got married, especially the woman, her job was the house and the children, I suppose. I didn't interfere. I had my work down there and she had hers.here. [emphasis added]

His wife, Grace, had a complementary story to tell; this was one couple that had spent their adult life together with little apparent conflict, because they had compatible expectations of the gender culture. ${ }^{5}$ Grace started training as a nurse, but gave it away when they married in 1947; she was 18 and he was 19. 'In those days', she said, 'once you got married, you more or less wasn't expected to work any more because your job went to a younger person'.

In the post-war years, he worked long hours to provide on one income. Grace recalled he:

... was working practically 7 days a week to keep us ... for a long time, he worked 12 hour shifts. He would get up in the morning and go to work, come home, have something to eat and go to bed, and that went on for a long, long time ... because we needed the money.

Significantly, he took pride in the fact that 'I never had my wife down the factory waiting for pay day, like a couple of other people did'. Men who required monitoring like this were unreliable and had been shamed in front of other men. He controlled the pay packet and gave her enough for housekeeping. Grace put it simply: 'because he was earning the money, that was his privilege'. When asked what she liked most about being a homemaker, Grace replied:

I don't think that you ever really thought about it. I think that was your life then and you didn't really think about it. That was it ... I was chief cook and bottle washer. He was always regarded as head of the family, even though he wasn't here, but I think I did a pretty good job, too. [emphasis added] 
These are vivid, spatial images of how the separate spheres of work and family were experienced in everyday life - his work 'down there' at work and hers 'here' at home, and his presence as head of the family even in his absence. The gender culture within which Len and Grace lived has a sense of being legible and taken-for-granted. For them, the male breadwinner/female carer model had the sheer, compelling power of obviousness. Their narrative is a reminder that cultural norms and values can be hegemonic less because they are firmly held convictions than because they have the apparent obviousness of common sense. Naturalness is the major chord of hegemony.

Another example of this sense of naturalness was the response of a manufacturing manager when asked about how he saw his position as a breadwinner:

Took it for granted. It was the role, an understood role. My wife enjoyed having the children and looking after the children and looking after me; I enjoyed being the breadwinner and it was just taken for granted. ${ }^{6}$

Similarly, a carpenter described what it was like to be a breadwinner:

It's just something you had to do and probably it's expected of you to get out and put the food and the money in the house and the woman took care of the house. You're brought up with [it] and it just happened.'

A draftsman also saw his position as something natural and learned: 'I guess l've been brought up with the thing that dad was the breadwinner and mum looks after the house and we took it for granted ... Things just happen. I didn't question them.'?

These descriptions of being 'brought up with' the expectation of 'an understood role' are in part about the inherited weight of family histories. But they are rarely about that weight as a burden. A research officer was asked if he ever considered being the breadwinner to be a burden:

That's a funny question. That's a question which arises out of a situation today because it wasn't ever in the minds of anybody in those days, after the war and during the ' 50 s. No woman who was married was expected to go out and work as well as keep house and look after children, and you can hardly look after children when you're not with them.'

Similarly, an insurance broker considered himself as:

... the breadwinner and the protector, these are old-fashioned phrases if you like. That was my place in the family. I understand that my wife had the same philosophy and she was the homemaker. She looked after the home and I'd provide ... the shelter and the food on the table, making sure it kept on coming in ... [it was] not a burden. It was just again an expectation. That was it. You're a father and that's your duty, it's your responsibility. You love your wife, you love your children, that was it. It was the role we're destined for. "i"

Values about duty, responsibility, expectation and destiny recur in these narratives, as men present breadwinning as the obvious pattern of their working and married lives. The expressions they use capture a sense of being immersed in a gender culture that was taken for granted and hegemonic. 
The expectations these men had of their lives and of themselves were often reinforced by the women they had married, as each fell into patterns they expected of each other. Mutual reinforcement linked breadwinning with motherhood as opposite sides of the same coin. This was captured by an insurance accountant, who described the gender arrangement in his marriage as 'an implied agreement that I was the breadwinner and she was the little lady in the kitchen' [emphasis added]." His wife, asked if they ever discussed or negotiated their respective roles, replied similarly: 'Just happened, that was life. Never a problem.' ${ }^{\prime 2}$ And a university lecturer said: 'I think it was something we didn't feel we needed to discuss. It seemed appropriate that I should continue in my career and once the children started to arrive, it seemed appropriate that she should stay home and look after them. ${ }^{13} \mathrm{His}$ wife, who trained as a scientist and returned to work later in life, agreed that there was no need to negotiate:

No, they just happened. They were male and female roles which our parents had had. We just automatically did the same thing ... I think I just accepted it as my lot in life and all my friends were doing the same. We weren't rebelling against anything, and Germaine Greer hadn't been heard of, but the next generation grew up very differently. ${ }^{14}$

It was more common to find among the middle-class interviewees this sense of simply being immersed in a naturalised gender culture, described as 'destiny', 'my lot in life', 'the accepted thing', the sheer obvious weight of the world. The absence of any sense of what Anthony Giddens (1991) calls reflexivity is nicely captured by the phrase 'implied agreement'.

Alongside these ideas of 'de facto breadwinners' were other men with a more normative attachment to the idea of being a provider. Normative breadwinners were more likely to have a strong investment in the identity of the breadwinner. Their narratives suggested that they thought a man ought to be the farnily provider. Rather than just take it for granted, they tended to argue the case and insist on breadwinning as the mark of manhood. As previously described, class was a major though only partial factor in this difference. Working-class men were more inclined to use a language that Joan Williams (2000) would characterise as that of status and entitlement, while middle-class men - with almost exactly the same arrangements in their work and family lives - tended to describe breadwinning as simply what they expected and what was expected of them. On the surface, there was little difference in the everyday arrangements of their married lives. And both remain 'traditional' orientations, in Anthony Giddens' sense of attitudes and identities considered to be pre-ordained and certain rather than reflexively adopted; in his view, the self in a traditional orientation is a given, while the self in post-traditional societies 'has to be reflexively made' (Giddens, 1991: 3).

But compared with 'de facto breadwinners', 'normative' breadwinners more often insisted on the prerogatives that flowed from being a breadwinner. Their narratives showed a stronger ideological attachment to the breadwinner identity and were more likely to link providing with control of money and familial authority. For example, a working-class man who maintained boilers at sea and then on land, was forthright when asked about his place in his family: 
I was the breadwinner, I was the authority figure... not that my children were misbehaved but if I spoke, they obeyed me ... When we started our family, which was very early after we got married, my wife stopped working completely. I considered it was alright because my. father had been the sole wage earner and it was my job as a wage earner to provide the money, and to provide as much money as I could to keep the family. ${ }^{\text {is }}$

A printer spoke of 'all men, to a lesser or greater degree, feel[ing] that they have a very, very strong obligation to provide for their families', ${ }^{16}$ while an accounts clerk said his wife stopped working when they married: 'it was unusual for wives to work ... That was the major reason why people waited to marry until they felt they were earning a sufficient income to support two.'"17

Similarly, a public servant said he was:

... very much the provider, very much the protector, very much the decision maker ... One felt that it was your duty not to have your wife worry about finances. So one didn't discuss much. You gave the necessary housekeeping and you worried about whether you could pay the next mortgage payment yourself. ${ }^{12}$

Normative ideas about being the provider were here connected with expectations of responsibility and duty, and to some extent with household authority. Often these men's ideas about breadwinning are simultaneously ideas about motherhood. An Italian factory worker insisted his wife give up work when their first child arrived:

I said to my wife, I would not like you to go to work. I'd rather do two jobs myself, which I did many times ... Look, the mother should be home. Nobody can look after children like mother does, years ago. Today, I don't know because it seems to me today it's vice versa. The woman want to be man and the man want to be woman."

The narratives of these men reveal an emotional and ideological investment in successful breadwinning as the measure of manhood. Their part of the gender bargain was marked out by what they did to earn the rights and responsibilities of providing and also marked out by what they did not do - in particular, caring for children.

\section{Manhood, Money And Misery}

When women were interviewed, many also reflected on their husbands as breadwinners. Often both partners were equally committed to their parts in the wider gender culture. For example, the wife of the accounts clerk who delayed marriage till he could support two on his salary described her position as 'just a wife and mother'. Asked what was the role of a father she said:

... 1 think they're the breadwinner and therefore it's important that they do have a right with the children, not just coming in and say, Good Day, and they leave them. Friends of mine, they used to have their children bathed and have had their tea and all, ready for bed, and when dad came in they were put to bed. We never did that. We always had tea together because I felt it was better for the children ... otherwise they are distant from their father and sometimes the children become frightened of their father, which isn't good." 
This is a relationship where both were strongly committed to the breadwinner model, and their expectations of self and of each other were mutually reinforcing. For some, a mutually agreed gender bargain could sit lightly enough; 'bringing home money to feed the family' and being regarded as 'head of the family' often went together but did not necessarily mean a marriage of domination and submission.

But some clearly expected submission to their authority as the head of the household to flow from their strong normative investment in breadwinning as the mark of manhood. This theme emerges most clearly in the narratives of the women interviewed, 13 (31 per cent) of whom spoke of dissatisfactions or frustrations with their share in the gender bargain. Their stories provide a more critical insight into breadwinning and its prerogatives in the post-war years. These women's experiences ranged from relatively mild financial control asserted by husbands to lives that were constrained, made miserable and sometimes violent by tyrannical husbands. Some described husbands exerting control over their spending, such as a woman, at home with small children in the 1950 s, who recalled her husband examining the bills: "he was in charge of the money, and when the [department store] account came ... he would say, "Now, why did you have to spend this amount?" ... It was horrible.'2t

Another example was a part-time teacher whose husband, a factory manager, required her to hand over her pay packet:

\begin{abstract}
... he just made decisions about what the money was spent on ... It was not an equal partnership. It was very much a "I'm the man and you're only the woman". Looking back on it now, I see that that was a different woman [to] the one that's around today, but that was how it was ... he just told me that that was how it was going to be. ${ }^{22}$
\end{abstract}

Frequently in the interviews with women who remember domineering husbands, money was the currency of control. One final example was a woman, married to an engineer, with a newborn baby in 1957, who received no income at all from her husband: "I left work and then I didn't have any money coming in because I didn't have a job, and my husband didn't give me housekeeping because his father had never given it to his mother'. He did most of the household shopping, and her parents gave her a little money regularly. $\mathrm{He}$ made it clear there was no room for discussion about their version of the breadwinner model: "My husband once said to me ... "It's my way or not at all". It took me a lot of years to think: "what a terrible thing to say to me". ${ }^{23}$

Because the breadwinner model is also a model about motherhood, the prerogatives of being a breadwinner meant - for some, perhaps many men - both an expectation of 'rightful authority' and a strict demarcation between work and home, between men's work and women's work. One small businessman who worked from home went to absurd lengths to insist on this division of labour. His wife gave a graphic account:

I was frequently told that [caring for the children] was my job and he would not step in even if he was a foot away... like [once] my daughter was outside when she was big enough to be in a play pen and she managed to pull the rug back and picked up a stone. And his workshop was just there, and he bellowed out to me to come and take the stone out of her mouth. and I said. 'Well. will you please do it'. 'No, this is your job'. ${ }^{44}$ 
Similarly a nurse who had married an Italian cabinetmaker told of his gradual decline into sickness, and the decline of their marriage into violence. Although she had become the sole breadwinner, he insisted on the terms of their original gender contract, including exercising authority and then violence if they disagreed:

... he ran the show even though he was sick .... He wouldn't do any housework or anything like that because that was not the man's role, so I had to keep that going and I had to go to work as well ... He was the head of the family. Any important decisions, he made ... [If] I decided to make a stand, it would come to blows. If he couldn't get me to go the way he wanted, I finished up getting knocked around. ${ }^{25}$

Not surprisingly their marriage ended in divorce. These examples are limit cases of the breadwinner model of marriage, when men were obsessive, authoritarian or violent in asserting the prerogatives of the breadwinner. Authoritarian men seemed as common among the middle class as among the working class, and the distinction between 'de facto' and 'normative' breadwinners does not simply map onto whether men were domineering or not.

We began with a vignette of a quiet working-class couple - Len and Grace - whose commitment to their parts in the gender culture seemed largely complementary. The following vignette of an upwardly mobile middle-class couple has the same surface arrangements of breadwinning and homemaking. But if the outward shape of their marriage was the same, its tenor was much harsher. This was an example of a man with an assertive and ideological commitment to being the breadwinner, along with expectations about his 'rightful authority' in the household. He had started as an office boy from a working-class suburb in Melbourne's west and then studied engineering at a Technical College, working his way up to be a plant engineer and manager. She had trained as a nurse before their marriage. At the aitar, she was 23 and he was 32, and their life trajectories were on a collision course.

He insisted she give up work; he had been brought up to see himself as the breadwinner.

... there was no question about that. I was brought up in an era and indoctrinated by both my mother and my father. If you can't afford to support a wife, don't get one ... So before we got married, I said to the girl who was to become my wife ... You're not going to work after we get married ... I saw a father's role first of all as supporting his family, so my wife didn't need to go to work and could devote herself to full-time training and bringing up of the children.

He had learnt about the responsibilities of manhood growing up in a working-class suburb: 'when I grew up ... any mother who worked or was not present in the home was looked down on within the street and the children were thought of as underprivileged' ${ }^{26}$ Like Len - who described working-class men being publicly shamed if their wives had to pick up their wages on pay day - this was another narrative of being humiliated in a local workingclass community, if a man did not fulfil his responsibilities as the provider. 
But the coltision between his sense of manhood and her experience of thwarted opportunities emerges painfully in her account of marriage as a loss of autonomy:

I loved nursing. It was freedom to me. The only freedom I've ever had was those 5 years when I lived in a nurses' home ... Before that, I had a strict mother at home. Very firm, couldn't do anything, and then I got away from her, and then I married a very heavy-handed husband ... Forty years of that. So it's all been prison except those 5 years in nursing ... he said that looking after him and his children and home should be enough for any woman... I've heard my husband say 'Well, if he can't keep his wife in order, how can he bloody run the company'. Obviously, keeping your wife in order is number one with that sort of man, and the way you do that, you don't let them get any money of their own. ${ }^{27}$

His was an example of a strong commitment to the full breadwinner package, where being the provider also meant control of money, a strict division of household labour and dominance as the head of the family.

Somehow their marriage had survived for over forty years. Perhaps one explanation lies in the shadow boxing to which each resorted; they both described their division of domestic labour with stories of artful stratagems. When asked who did what of the domestic work, she replied simply:

Cut and dried, man's work and women's work. When I did my mother-in-law's garden when we were first married, she came up to me, she was 73, and she said, 'if you do men's work, you'll be left doing both lots' ... she was trying to tell me something. Be careful, she was saying, or you'll be landed with everything.

And he, too, responded to a similar question by telling a story of how 'inept' he was with children, and being inept had its purposes. When he first became a father, his boss had told him:

... to make sure if I was asked to put a napkin on, to make sure I did it properly, and leave plenty of opening around the legs, so if anything were to fall out it could, and he said, that way I'll never be asked to do it again, and I wasn't.

With little love between them, coercion and shadow boxing were the prime currency of their lives together. That their marriage had not imploded was partly a testimony to the strength of the gender culture in which they were both immersed and partly a result of her commitment to the selflessness expected of her - she considered leaving but said she stayed for the sake of the children.

\section{Conclusion}

These interviews demonstrate some remarkable uniformity of experience in the post-war years. Virtually all these men were breadwinners, though some had wives who worked part-time. But below the surface of this similarity, variations can be discerned between those vigorously committed to being the breadwinner and those who simply accepted it as their lot. This was the difference between 'weak' and 'strong' investments in 
breadwinning as a marker of masculine identity and as a source of authority. Analysing the narratives through which men and women described breadwinning allows us to see different meanings lying below the surface. And if what being a breadwinner meant to them varied, to some extent this was a matter of class difference. It was the variation in meaning between the insurance accountant, who airily described 'an implied agreement that I was the breadwinner and she was the little lady in the kitchen' (and was not contradicted by his wife), and the engineer, who had told his (appalled) wife that 'it's my way or not at all'.

Differences in these narratives also signify that men and women lived out the gender culture in ways constructed within their marriage. What breadwinning meant was understood through the dialogue, negotiation or conflict of their lives together. The meaning of breadwinning was in part constructed 'intersubjectively'. Many of these men refer to the demonstration effect of learning gender from their parents. As one country school teacher put it: 'you remembered what your father did, what your mother did in the house ... Our roles were handed down. ${ }^{28}$ Just as fundamentally, what breadwinning meant was constructed mutually between men and women. Some collaborated by taking their parts for granted, while others ground out a dialogue of domination and submission. The work of 'doing gender' was rarely conducted in open negotiation, was often constructed as an 'implied agreement' and was too often imposed on the dictated terms of 'it's my way or not at all'. These differences in turn reflected the quality and the tenor of relationships.

It is one of the ironies of social enquiry that concepts such as the breadwinner become more sharply focused as they recede in social experience. Naturalness can make social experiences opaque, while the reputed 'demise' of the male breadwinner has brought him into sharper relief. The breadwinner model may persist in the ways that work is organised, but only one-third of working families in Australia with dependent children still conform to the 'traditional' (single-income) breadwinner model that was so pervasive in the post-war years (Buchanan and Thornthwaite, 2001: 20). Changes in the labour market, the collapse of Full Employment, the erosion of the arbitrated 'family wage' and women's refusal to any longer accept the terms of the old gender bargain have all contributed to the withdrawal of the male breadwinner. As Mintz puts it: 'with the erosion of the family wage and its replacement by the individual wage, a central component of male identity, a critical factor in defining men's time commitment and roles in the family, has given way' (Mintz, 1998: 27, and see Crompton and Harris, 1999).

We have only to mention these changes to suggest how the values of men and women recalling the post-war high tide of domesticity are now fading into the past. But just as there may be cross-national variations between 'strong' and 'weak' breadwinner models, so there are important subtleties in Australian post-war experiences. The difference between a taken for granted 'de facto' and a more insistent 'normative' attachment to the breadwinner model might signify little for the study of the surface patterns of work and family. But it is a marked difference of tone in the social and emotional experience of many men and women. Even at the high water mark of its apparent uniformity, rather than being 
a known and fixed starting point, the breadwinner model could be lived out as a range of meanings within the dominant gender culture.

\section{Acknowledgment}

This paper is based on research conducted with Belinda Probert and John Wiseman from 1997 to 2000 on an ARC Large Grant project. The older group whose views are explored here was complemented by an equivalent group of men and women with young children in the late 1990s. Included in the older age cohort were 17 married couples, who were interviewed separately. Across the two age cohorts, we recorded focus group interviews with a total of 42 people and then individual in-depth, semi-structured interviews with a further 168 people. Interviewees came from a variety of socio-economic backgrounds and experiences, and while some migrants were included, we were not attempting a representative sample of the ethnic composition of Australia in either age cohort. Interviewees were invited to tell the story of their working lives and family lives, while they were being taken through a series of open-ended questions about work, family and community. The resulting transcripts were then subjected to detailed narrative analysis, a method which, as Somers and Gibson (1994) point out, recognizes the possibility of ambiguous and even contradictory narratives or story lines (see also Hinchman \& Hinchman, 1997).

\section{Endnotes}

1. M5/32 (\#84) carpenter, 1 child in 1957.

2. M5/9 (\#28) research chemist, children after 1957, wife dentist ( $F 5 / 13)$.

3. M5/36 (\#108) printer, no children, wife a Communist Party official.

4. Pseudonym-M5/19 (\#58) no religion, process worker \& foreman, 5 children in 1957, wife (F5/25) home duties.

5. Pseudonym - F5/25 (\#61) no religion, home duties, 5 children in 1957, husband (M5/19) process worker.

6. M5/12 ( $\$ 41)$ manufacturing manager, 2 children in 1957.

7. M5/6 ( $\$ 20)$ carpenter/builder, migrated from UK in 1922, 3 children in 1957.

8. M5/34 (\#96) draftsman, 3 children in 1957, wife home duties (F5/36).

9. M5/27 (\#76) experimental research officer, 3 children in 1957, wife home duties ( $F 5 / 33$ ).

10. M5/15 (\#48) insurance broker, 2 children in 1957, wife part-time work (F5/18).

11. MS/23 (\#66) accountant insurance industry, 2 children in 1957, wife home duties (F5/27).

12. F5/27 (\#67) home duties, 2 children in 1957, husband accountant (M5/23).

13. M5/16 (\#49) university lecturer, 1 child in 1957, wife home duties (F5/17).

14. $\mathrm{F} 5 / 17$ (\#46) home d uties, $I$ child in 1957 , husband university lecturer (M5/16).

15. M5/29 (\#81) marine engineer - boiler maintenance, 3 children in 1957, wife home duties. 
16. M5/28 ( \#79) printer -foreman, 1 child in 1957, wife home duties.

17. M5/24 (\#70) accounts clerk, 2 children in 1957, wife home duties (F5/35).

18. M5/14 (\#47) public servant, Catholic, 1 child in 1957, wife home duties (F5/21).

19. Mf/11 ( \$37) factory worker, children later than 1957.

20. F5/35 (\#80) home duties, 2 children in 1957, husband accounts clerk (M5/24).

21. F5/10 ( $\# 22)$ home duties, newborn baby in 1957.

22. F5/44 (\#94) part-time teacher, l child in 1957, husband factory manager.

23. $F 5 / 30(\# 72)$ home duties, 1 child in 1957 , husband engineer.

24. F5/4 (\#8) home duties, 2 children in 1957.

25. F5/24 (\#60) nurse, sole income earner, children born after 1957 , husband a cabinet maker / invalid.

26. $\mathrm{M} 5 / 10(\$ 32)$ plant engineer, no children in 1957 , married in 1958 , wife (F5/15) not working.

27. F5/15 (\#40) home duties, no children in 1957, married 1958, husband plant engineer (M5/10).

28. M5/33 (\#89) school teacher, 4 children in 1957, wife home duties but later returned to teaching.

\section{References} Baldock, C. \& Cass, B. (eds) (1988) Women, Social Welfare and the State, $2^{\text {ed }}$ ed, Sydney, Allen
\& Unwin.

Bryson, L. (1992) Welfare and the State: Who Benefits? London, Macmillan.

Bryson, L. (1995) 'Two welfare states: One for women, one for men', in A. Edwards and S. Magarey (eds), Women in a Restructuring Australia: Work and welfare, Sydney, Allen \& Unwin, 60-76.

Buchanan, J. \& Thornthwaite, L. (2001) Paid work and parenting: Charting a New course for Australian families, ACIRRT, University of Sydney.

Cass, B. \& Smyth, P. (eds) (1998) Contesting the Australian Way: states, markets and civil society, Melbourne, Cambridge University Press.

Castles, F. (1985) The Working Class and Welfare, Sydney, Allen \& Unwin.

Castles, F. \& Shirley, I. (1996) 'Labour and Social Policy: Gravediggers or Refurbishers of the Welfare State', in F. Castles, R. Gerritsen and J. Vowles (eds), The Great Experiment: Labour Parties and Public Policy Transformation in Australia and New Zealand, Sydney, Allen \& Unwin, 88-106.

Cohen, T. (1993) 'What Do fathers Provide?', in Jane C. Hood (ed), Men, Work and Family, Newbury Park, Sage, 1-22.

Connell, R.W. (1995) Masculinities, Sydney, Allen \& Unwin.

Crompton, R. \& Harris, F. (1999) 'Employment, Careers and Families: The significance of choice and constraint in women's lives', in Crompton, R. (ed), Restructuring Gender Relations and Employment: The Decline of the Male Breadwinner, Oxford, Oxford University Press, 128-149.

Fuster, R.A.\& Stewart, S.E. (1991), Australian Economic Statistics, 1949-50 to 1989-90, Melbourne, Reserve Bank of Australia. 
Giddens, A. (1991) Modemity and Self-identity: Self and Society in the Late Modern Age, Oxford, Polity.

Gilding, M. (1991) The Making and Breaking of the Australian Family, Sydney, Allen \& Unwin.

Hinchman, L.P \& Hinchman, S.K. (eds) (1997) Memory, Identity, Community: the idea of narrative in the human sciences, Albany, State University of New York Press.

Macintyre, S. (1985) Winners and Losers: the pursuit of social justice in Australian history, Sydney, Allen \& Unwin.

Mintz, S. (1998) 'From Patriarchy to Androgyny and Other Myths: Placing Men's Family Roles in Historical Perspective', in Alan Booth and Ann C. Crouter (eds), Men in Families: When do they get involved? What difference does it make?, Mahwah, New Jersey, Lawrence Erlbaum Associates, 3-30.

Murphy, J. (1995) 'Shaping the Cold War Family: Politics, Domesticity and Policy Interventions in the 1950', Australian Historical Studies, Vol. 26, No. 105, 544-567.

Murphy, J. (2000) Imagining the Fifties: Private Sentiment and Political Culture in Menzies' Australia, Sydney, University of New South Wales Press and Pluto Press.

Peel, M. (1995) Good Time, Hard Times: The past and the future in Elizabeth, Melbourne Melbourne University Press.

Pfau-Effinger, B. (1993) 'Modernisation, Culture and Part-Time Employment: The Example of Finland and West Germany', Work, Employment and Society, 7, (3): 383-410.

Pfau-Effinger, B. (1999) 'The Modernization of Family and Motherhood in Western Europe', in Crompton, R. (ed), Restructuring Gender Relations and Employment: The Decline of the Male Breadwinner, Oxford, Oxford University Press, 60-79.

Pleck, J. (1987) 'American Fathering in Historical perspective', in M. Kimmel (ed) Changing Men: New directions in research on men and masculinity, Newbury Park, Sage, 83-97.

Richmond, K. (1974), 'The workforce participation of married women in Australia', in D. Edgar (ed), Social Change in Australia, Melbourne, Cheshire, 267-305.

Rotundo, E.A. (1993) American Manhood: Transformations in Masculinity from the Revolution to the Modern Era, New York, Basic Books.

Sainsbury, D. (1996) Gender, Equality and Welfare States, Cambridge, Cambridge University Press.

Somers, M.R. and Gibson, G.D. (1994) 'Reclaiming the Epistemological "Other": Narrative and the Social Construction of Identity', in Craig Calhoun (ed), Social Theory and the Politics of Identity. Oxford, Blackwell, 37-99.

Watts, R. (1997) 'Ten Years on: Francis G. Castles and the Australian "wage-earners' welfare state", Australian and New Zealand Journal of Sociology, 33(1): 1-15.

Williams, J. (2000) Unbending Gender: Why family and work conflict and what to do about it, New York, Oxford University Press.

JOHN MURPHY, Centre for Applied Social Research, School of Social Science and Planning, RMIT University 


\section{University Library}

\section{- M M I N E R VA A gateway to Melbourne's research publications}

Minerva Access is the Institutional Repository of The University of Melbourne

Author/s:

MURPHY, JOHN

Title:

Breadwinning: accounts of work and family life in the 1950s

Date:

2002-04

Citation:

Murphy, J. (2002). Breadwinning: accounts of work and family life in the 1950s. Labour and Industry, 12(3), 59-75.

Publication Status:

Published

Persistent Link:

http://hdl.handle.net/11343/34070 